\title{
Comparison of Essential Oil Composition, Phenolic Compound and Biological Activities of Salvia microphylla and Teucrium polium (Lamiaceae)
}

\author{
Ayda Khadhri ${ }^{1}$, Chedia Aouadhi ${ }^{2}$, Eric Masson ${ }^{3}$ and Antonio Pizzi ${ }^{4,5,}$ \\ ${ }^{1}$ Plant, Soil and Environment Interactions Laboratory, Faculty of Sciences, University of El-Manar II, Tunis, Tunisia \\ ${ }^{2}$ Bacteriology and Biotechnology Development Groups, Epidemiology Laboratory and Veterinary Microbiology, Pasteur Institute of \\ Tunis, University of El-Manar II, Tunis, Tunisia \\ ${ }^{3}$ CRITTBois, Epinal, France \\ ${ }^{4}$ LERMAB, University of Lorraine, Epinal, France \\ ${ }^{5}$ Department of Physics, King Abdulaziz University, Jeddah, Saudi Arabia \\ *Corresponding Author: Antonio Pizzi. Email: antonio.pizzi@univ-lorraine.fr
}

Received: 26 August 2021 Accepted: 19 October 2021

\begin{abstract}
Salvia microphylla and Teucrium polium are medicinal and aromatic plants with ethnobotanical uses. The present study was conducted to investigate the chemical composition of Salvia microphylla and Teucrium polium essential oils, the secondary metabolites, and the biological activities of their infusion and methanolic $(\mathrm{MeOH})$ extracts. Essential oils were extracted by hydrodistillation from shoots Salvia microphylla and Teucrium polium. Phenolic content, antioxidant and antimicrobial activities were determined. Gas chromatography-mass spectrometry (GCMS) results showed the presence of significant qualitative and quantitative variations for the composition of the both essential oils (EO). Salvia microphylla EO were most complex and present 70 compounds with the major components were $\beta$-caryophyllene (13.32\%), 1,8 cineole (11.25\%), Cis p-Menthane-3-one (10.74\%), and $\beta$-Selinenol (9.71\%). Where in the Teucrium polium EO, 45 compounds were identified with the important components are $\beta$-cadinene (10\%), $\beta$-citronellol (8.5\%), Carvacrol (7.63\%), and Eugenol (7.15\%). Obtained results showed that both plant are very rich in secondary metabolites. Extracts isolated from Salvia microphylla presented the highest contents in the phenolic compound than extracted from Teucrium polium. The antioxidant activity data demonstrated that all extracts showed strong antioxidant and radical scavenging activities. Essential oil and methanol extracts presented a potential for antimicrobial activities against all tested microorganisms. The obtained results highlight the potential use of Salvia microphylla and Teucrium polium as possible natural antioxidant substances and sources of bioactive molecules.
\end{abstract}

\section{KEYWORDS}

Salvia microphylla; Teucrium polium; phenolic compounds; antioxidant; antimicrobial activity; essential oil

\section{Introduction}

The Lamiaceae family is a very diverse family with 6,900-7,200 species divided into 236 genera [1]. Some species of this family are of economic importance due to their content in essential oil, in polyphenolic compounds, and their use in traditional medicine it which is often linked to the presence of 
diterpenoids [2-4]. This family is widespread in tropical and subtropical regions, but mainly in the Mediterranean region [5-6]. Among the Lamiaceae family, we find Salvia and Teucrium genus that comprises several species.

The genus Salvia (sage) is one of the most important genera of the Lamiaceae family comprising nearly 1000 species identified throughout the world [6,7]. They are also good widespread in temperate and subtropical zones $[8,9]$.

Many species of Salvia are used as herbal tea, as condiments, in cosmetics, in the food and pharmaceutical industries. Several species of Salvia are known for their biological and pharmacological properties including their anti-bacterial, anti-virals, anti-oxidants, anti-malarials, anti-inflammatories, antidiabetics, cardiovascular and anti-cancer effects. Some of these properties have been attributed to their essential oils $[10,11]$. These species are rich in flavonoids and phenolic compounds such as caffeic, rosmarinic, chlorogenic, ellagic, and gallic acids [12,13].

Salvia microphylla is commonly used in the treatment of folk illnesses: to treat an upset stomach, just take a glass of salvia infusion that is consumed before breakfast and again throughout the day as needed. The tea must be made with Salvia microphylla and Agastache spp. (Lamiaceae) and drunk for 9 days while a paste made from Agastache and Salvia microphylla must be applied each day to the child's body while invoking the spirits of the plants [14]. The chemical constituents of aerial parts of Salvia microphylla include triterpenoids erythrodiol-3-acetate, lupeol, and oleanolic acid. Oleanolic acide exhibits antimicrobial, anti-ulcer, and anti-inflammatory activities [15].

The generic name of germander means in Latin "teucrion" in Greek "tєvкріon" of teucros, Trojan prince who would have discovered the medicinal properties of the plant [16]. The genus Teucrium is one of the most important genera of the Lamiaceae family. This genus is divided into 340 species and varieties around [17].

The genus Teucrium has been widely used in traditional pharmacopeia for over 2000 years [18] in many regions of the world. The pharmacological properties of some species of this genus have been demonstrated in scientific studies. The diseases for which these species used are very diverse. Teucrium polium is utilized as a depurative and remedy for liver disease, hypertension, in the treatment of gastroduodenal ulcers and hyperlipidemia [19,20]. Teucrium polium L. has long been recognized in folk medicine for the pathophysiological treatment of many conditions [21], such as inflammation and rheumatism. Its extract has shown hypotensive, anti-spasmodic, anti-bacterial, diaphoretic anti-pyretic, invigorating, analgesic effects [22] and anti-oxidant effects [20,23].

The species Teucrium polium (Lamiaceae) has been the subject of several studies over the years [24]. These investigations revealed the presence of different classes of compounds such as fatty acid esters, diterpenes, monoterpenes, sesquiterpenes, polyphenols, and flavonoids (cirsimaritin, cirsilol, cirsilineol, 5hydroxy-6,7,3',4'-tetramethoxyflavone, salvigenin, apigenin-5-galloylglucoside, apigenin-7-glucoside, vicenin, and luteolin-7-glucoside) [25].

In this study, total phenolic, flavonoids, and condensed tannin contents of infusion and methanolic extracts obtained from the shoots of Salvia microphylla and Teucrium polium originated from North Tunisia were evaluated. In addition, the antioxidant and antimicrobial activities of such extracts were studied. Moreover, the chemical composition of the essential oils of Salvia microphylla and Teucrium polium were also determined. This is the first study carried out in Tunisia on Salvia microphylla. The ultimate objective of this work was to find new potential sources of natural antioxidants and antimicrobial agents for the food industry. 


\section{Materials and Methods}

\subsection{Plant Material}

Salvia microphylla (20 plants) and Teucrium polium (30 plants) shoots were collected during summer (in flowering stage), Mars 2013, in Jendouba, Northern Tunisia, and T. polium was identified according to the "Flore de la Tunisie" [26]. Concerning Salvia microphylla, the plant was identified out by R. El Mokni, botanist at the University of Science of Bizerte. Voucher specimens were preserved in our laboratory for further reference. Shoots were dried for two weeks.

\subsection{Phytochemical Study}

The phytochemical examination is necessary to identify the major families of compounds existing in Salvia microphylla and Teucrium polium. The presence of these secondary metabolites was characterized using the technique previously described by Karumi et al. [27].

The alkaloids have been identified by Burchard reagent. $6 \mathrm{~mL}$ of each tested solution was evaporated to dryness. The addition of 2 drops of reagent Burchard on alcoholic solution caused a reddish-brown precipitate and indicates a positive reaction.

For the detection of flavonoids, $2 \mathrm{~mL}$ of plant extracts are treated with a few drops of $\mathrm{HCl} 37 \%(\mathrm{~V} / \mathrm{V})$, and $0.5 \mathrm{~g}$ of magnesium turnings $\mathrm{Mg}$. The positive test is marked by the appearance of pink or red color which characterizes flavonoids.

The reaction of ferric chloride $\left(\mathrm{FeCl}_{3}\right)$ was used to characterize the tannins. To $2 \mathrm{~mL}$ of extracts were added 2 or 3 drops of the solution of $\mathrm{FeCl}_{3} 1 \%(\mathrm{~V} / \mathrm{W})$. A positive test is indicated by the appearance of a blue-black color (gallic tannins) or blue-green (catechins tannins).

\subsection{Preparation of Plant Extracts}

\subsubsection{Infusion Extract}

The infusion, water extraction, is the most common mode and classic manual of herbal remedies. This extract was prepared as follows: $10 \mathrm{~g}$ of each shoots plants were added to $100 \mathrm{~mL}$ of boiling water. The mixture is let for rest for fifteen minutes in a closed container, glass or porcelain, stirring occasionally. Then, the liquid was filtered through filter paper then freeze-dried, and lyophilized.

\subsubsection{Methanolic Extract}

$50 \mathrm{~mL}$ methanol was added to $5 \mathrm{~g}$ of Salvia microphylla and Teucrium polium shoots (80\%). After $30 \mathrm{~min}$ of stirring, the extracts were stored at $4^{\circ} \mathrm{C}$ in the dark for $24 \mathrm{~h}$ before being filtered through ashfree filter paper (Whatman No. 4). As a result, the methanol were evaporated and the extracts were kept at $4^{\circ} \mathrm{C}$ for tests.

\subsubsection{Essential Oil (EO)}

The EO was extracted by hydrodistilling for $3 \mathrm{~h} 100 \mathrm{~g}$ of Salvia microphylla and Teucrium polium airdried. The dry weight of the plant material was then used to determine the oil yields from the shoots. Obtained oils were kept in dark at $4^{\circ} \mathrm{C}$ for one month.

\subsection{Identification of Essential Oil}

Gas chromatography-mass spectrometry (GC-MS) was used to identify the chemical composition of essential oils [4].

Oil components were identified by comparing their retention indices relative to $\left(C_{8}-C_{22}\right) n$-alkanes to those reported in the literature or to those of real compounds in the authors' laboratory. Their recorded mass spectra were compared to those stored in the Wiley/NBS mass spectral library of the GC-MS data 
system as well as other published mass spectra [28]. Peak area normalization was used to get the percentage composition without the use of correction variables.

\subsection{Determination of the Amounts of Phenolic Compounds}

\subsubsection{Total Phenolic Content}

The Folin-Ciocalteu reagent was used to measure total phenolic, as described by Dewanto et al. [29]. The total phenolic content of every extract was estimated as milligrams of gallic acid equivalents per gram of dry weight (mg GAE/g DW). From a calibration curve with gallic acid $(y=0.0074 x+0.0737)$.

\subsubsection{Estimation of Total Flavonoid Contents}

According to Dewanto et al. [29], total flavonoids were determined using a colorimetric method. The total flavonoid content was estimated as $\mathrm{mg} \mathrm{CE}$ (catechin equivalents) $/ \mathrm{g} \mathrm{DW}$. The catechin calibration curve range $(\mathrm{y}=0.0033 \mathrm{x}+0.0184)$.

\subsubsection{Total Condensed Tannins Assay}

Total condensed tannins was determined according to the method of Sun et al. [30]. Results were expressed as mg TAE (Tannic acid equivalents)/g dry weight. Tannic acid calibration curve range $(\mathrm{y}=\mathrm{x} /$ $0.5184)$.

\subsection{Antioxidant Activity}

3 classic tests were used, in this work, to evaluate the antioxidant activity of Salvia microphylla and Teucrium polium extracts: iron-chelating power, the reducing power of iron, and test of radical scavenging 1,1 diphenyl-2-picrylhydrazyl (DPPH).

\subsubsection{DPPH Assay}

The electron donation ability of the obtained extracts was measured by bleaching of the purple-colored solution of 1,1-diphenyl-2-picrylhydrazyl radical (DPPH) according to the method of Hatano et al. [31]. A $1 \mathrm{~mL}$ aliquot of the extract at different concentrations $(0,1,2,3,4$, and $5 \mathrm{mg} / \mathrm{mL})$ was added to $2000 \mu \mathrm{L}$ of $\mathrm{DPPH} \bullet$ working solution. The absorbance reading was taken after $30 \mathrm{~min}$ of incubation in the dark at $517 \mathrm{~nm}$. Percentage inhibition (PI \%) of free radical DPPH was calculated as follow:

PI $(\%)=\left(\left(\mathrm{A}_{\text {blank }}-\mathrm{A}_{\text {sample }}\right) / \mathrm{A}_{\text {blank }}\right) \times 100$, where $\mathrm{A}_{\text {blank }}$ is the absorbance of the control reaction and $\mathrm{A}_{\text {sample }}$ is an absorbance in the presence of infusion extract. Extract concentration providing 50\% inhibition $\left(\mathrm{IC}_{50}\right)$ was calculated from the regression equation prepared from the extracts concentration and their percentual inhibition. Samples were analyzed in triplicate.

\subsubsection{Tests for Reduction Capability}

T Oyaizu's method was used to determine reducing power [32]. Sodium phosphate buffer $(500 \mu \mathrm{L}$, $200 \mathrm{mM}, \mathrm{pH}$ 6.6) mixed with potassium ferricyanide (1\%) $2.5 \mathrm{~mL}$ were added to a number of extracts $(200 \mu \mathrm{L})$ concentrations $(0,1,2,3,4$ and $5 \mathrm{mg} / \mathrm{mL})$ and thoroughly mixed. After incubation (20 min, at $50^{\circ} \mathrm{C}$ ) trichloroacetic acid $10 \%$, w/v was then added in an amount of $2.5 \mathrm{~mL}$ and the whole underwent a 10 min centrifugation at $650 \mathrm{rpm} .500 \mu \mathrm{L}$ of the top layer were then added of $100 \mu \mathrm{L}$ of $0.1 \%$ ferric chloride and of $500 \mu \mathrm{L}$ deionized water and the whole thoroughly mixed. Determination of the absorbance was carried out at $700 \mathrm{~nm}$ : the higher is the level of reducing power the higher is the absorbance measured. The extract concentration providing 0.5 of absorbance $\left(\mathrm{IC}_{50}\right)$ was calculated from The $700 \mathrm{~nm}$ absorbance $v s$. extract concentration graph was used to determine at what concentration of extract an absorbance of 0.5 (IC50) was obtained. 


\subsubsection{Tests for the Determination of Iron Chelation Ability}

The Decker and Welch methodology was used [33] to determine the ability of chelation of ferrous ions. Different extract concentrations $(0,1,2,3,4$ and $5 \mathrm{mg} / \mathrm{mL})$ of extract were added in $0.1 \mathrm{~mL}$ amount to $\mathrm{FeCl}_{2}$ $4 \mathrm{H}_{2} \mathrm{O}(0.05 \mathrm{~mL} ; 2 \mathrm{mM})$. The mixture was then vigorously stirred for $5 \mathrm{~min}$, ferrozine $(0.1 \mathrm{~mL} ; 5 \mathrm{mM})$ premixed with distilled water $(2.75 \mathrm{~mL})$ was then added and mixed thoroughly. The mixtures were left resting for $10 \mathrm{~min}$ at ambient temperature. The absorbance was then determined at $562 \mathrm{~nm}$.

\subsection{Antimicrobial Activity}

Given that, the yields of both tested essential oils are weak, their antimicrobial effect was evaluated only against 3 pathogenic referenced bacteria (Escherichia coli ATCC 8739, Pseudomonas aeruginosa ATCC 27853, and Listeria monocytogenes ATCC). While for methanolic extracts, 9 micro-organisms as described by Bannour et al. [34] were used for evaluating their antibacterial and antifungal powers.

The antimicrobial possess of evaluated extracts were determined using 2 methods: disc diffusion assay (determination of the diameters of inhibition zones) and the broth dilution method (determination of the minimum inhibitory concentrations (MIC) and minimum bactericidal concentrations (MBC) as described by Bannour et al. [34].

Gentamicin (10 mg/disk) and amphotricin B (20 mg/disk) were used as a positive reference for bacteria and fungi, respectively.

\subsection{Statistical Analysis}

SAS v. 9.1.3 was used to analyze the data (SAS, 1990). Any significant variations between solvents and samples were compared using analysis of variance (ANOVA) and Duncan's multiple range approach. Means and standard deviations were used to express the data. $P<0.05$ was used to determine whether differences were significant. All of the analyses were done in duplicate, and the results were averaged over three replicates.

\section{Results}

\subsection{Phytochemical Tests}

The phytochemical tests were carried out with the objective of highlighting the presence or absence of secondary metabolites in the shoots of the studied plants and this manifests itself by characterization reactions, which consist of precipitation or coloring phenomena by appropriate reagents for each metabolite. The characteristic tests of different chemical groups summarized in Table 1 demonstrated that the extracts obtained from S. microphylla and T. polium contain flavonoids, tannins, and phenolic derivatives.

Table 1: Results of the reactions characteristic of different chemical groups looked in Teucrium polium and Salvia microphylla

\begin{tabular}{lll}
\hline Secondary metabolites & T. polium & S. microphylla \\
\hline Alkaloids & - & - \\
Flavonoids & + & + \\
Tannins & + & + \\
Phenolic derivatives & + & + \\
\hline
\end{tabular}

\subsection{Essential Oil Composition}

The chemical composition of essential oils obtained from 2 species of the Lamiaceae genus (T. polium and S. microphylla) were determined by GC-MS analysis. Table 2 represents the identified compounds, their percentages as well as the retention indices. Although the existence of some commune compounds between 
the 2 studied plants; significant qualitative and quantitative variations were observed for the composition of the both essential oils. In fact, S. microphylla EO was most complex and presents 70 compounds with the major components are $\beta$-caryophyllene (13.32\%), 1,8 cineole (11.25\%), Cis p-Menthane 3 one (10.74\%), and $\beta$-Selinenol (9.71\%). Where in the T. polium EO, 45 compounds were identified with the important components are $\beta$-cadinene (10\%), $\beta$-citronellol (8.5\%), Carvacrol (7.63\%), and Eugenol (7.15\%).

Table 2: Chemical composition of essential oils of Teucrium polium and Salvia microphylla

\begin{tabular}{|c|c|c|c|}
\hline $\mathrm{RI}^{\mathrm{a}}$ & Compounds $^{\mathrm{b}}$ & T. polium & S. microphylla \\
\hline 915 & 3-carene & $0.09 \pm 0.01$ & $0.04 \pm 0.03$ \\
\hline 921 & $\alpha$-thujen & - & $0.12 \pm 0.07$ \\
\hline 922 & $\alpha$-phellandren & $0.66 \pm 0.00$ & - \\
\hline 929 & $\alpha$-pinene & $1.32 \pm 0.03$ & $2.30 \pm 0.01$ \\
\hline 930 & 1-Phenyl isobutane & $1.83 \pm 0.02$ & - \\
\hline 947 & Camphene & $0.07 \pm 0.01$ & $2.63 \pm 0.05$ \\
\hline 976 & Sabinene & $0.07 \pm 0.01$ & - \\
\hline 987 & $\beta$-pinene & $1.02 \pm 0.00$ & $1.23 \pm 0.01$ \\
\hline 1027 & Amyl vinyl carbinol & $0.07 \pm 0.01$ & - \\
\hline 1036 & $\beta$-myrcene & $0.43 \pm 0.01$ & $0.06 \pm 0.01$ \\
\hline 1058 & $\alpha$-terpinen & $0.26 \pm 0.01$ & $0.17 \pm 0.02$ \\
\hline 1073 & O-cymene & $4.77 \pm 1.03$ & $0.40 \pm 0.01$ \\
\hline 1074 & Trans linalool oxide & - & $0.05 \pm 0.00$ \\
\hline 1085 & Limonene & $0.61 \pm 0.00$ & $0.02 \pm 0.00$ \\
\hline 1088 & 1,8 cineole & $0.17 \pm 0.01$ & $\mathbf{1 1 . 2 5} \pm 1.07$ \\
\hline 1102 & $\delta$-terpinene & $0.28 \pm 0.02$ & $0.04 \pm 0.01$ \\
\hline 1157 & 2-carene & $0.09 \pm 0.01$ & $2.92 \pm 0.04$ \\
\hline 1162 & Cis ocimene & - & $0.10 \pm 0.02$ \\
\hline 1169 & $\beta$-linalool & $3.26 \pm 0.09$ & $0.08 \pm 0.01$ \\
\hline 1182 & $\alpha$-thujone & $0.78 \pm 0.03$ & $2.32 \pm 0.05$ \\
\hline 1188 & $\beta$-terpineol & $0.37 \pm 0.02$ & $0.83 \pm 0.04$ \\
\hline 1203 & $\alpha$-campholenal & $0.45 \pm 0.02$ & $0.31 \pm 0.02$ \\
\hline 1217 & Cis piperitol & $0.49 \pm 0.01$ & $0.04 \pm 0.01$ \\
\hline 1232 & Cis verbenol & $0.15 \pm 0.01$ & $0.15 \pm 0.08$ \\
\hline 1295 & Cis p-Menthane 3 one & $1.09 \pm 0.03$ & $\mathbf{1 0 . 7 4} \pm 1.05$ \\
\hline 1307 & 3 -Thujen 2 one & $0.55 \pm 0.02$ & $0.06 \pm 0.01$ \\
\hline 1336 & Germacrene B & $2.41 \pm 0.23$ & $0.07 \pm 0.01$ \\
\hline 1351 & Myrtenol & $3.06 \pm 0.02$ & $0.12 \pm 0.04$ \\
\hline 1376 & Verbenone & $0.54 \pm 0.11$ & $0.11 \pm 0.03$ \\
\hline 1380 & $\beta$-citronellol & $\mathbf{8 . 5 5} \pm 0.34$ & $0.21 \pm 0.05$ \\
\hline 1393 & Trans Geraniol & $3.43 \pm 0.14$ & $0.03 \pm 0.00$ \\
\hline
\end{tabular}




\begin{tabular}{|c|c|c|c|}
\hline $\mathrm{RI}^{\mathrm{a}}$ & Compounds $^{\mathrm{b}}$ & T. polium & S. microphylla \\
\hline 1399 & Humulen & $2.66 \pm 0.10$ & $0.06 \pm 0.01$ \\
\hline 1415 & $\alpha$-Neoclovene & $1.56 \pm 0.13$ & $0.54 \pm 0.02$ \\
\hline 1420 & Carvacrol & $\mathbf{7 . 6 3} \pm 1.91$ & $0.08 \pm 0.01$ \\
\hline 1437 & Cubebene & $0.30 \pm 0.06$ & - \\
\hline 1439 & Eugenol & $7.15 \pm 2.02$ & - \\
\hline 1443 & Copaene & $1.02 \pm 0.08$ & $0.30 \pm 0.03$ \\
\hline 1445 & $\alpha$-panasinsen & - & $0.43 \pm 0.01$ \\
\hline 1446 & $\beta$-caryophyllene & $0.13 \pm 0.01$ & $\mathbf{1 3 . 3 2} \pm 1.32$ \\
\hline 1449 & Azulene & - & $0.36 \pm 0.01$ \\
\hline 1454 & $\delta$-Guaiene & $0.61 \pm 0.03$ & $3.88 \pm 0.10$ \\
\hline 1457 & $\alpha$-caryophyllene & $1.92 \pm 0.07$ & $0.74 \pm 0.01$ \\
\hline 1460 & $(+)$ Aromadendrene & $0.56 \pm 0.03$ & - \\
\hline 1463 & Valencen & - & $1.37 \pm 0.50$ \\
\hline 1465 & $\delta$-Muurolene & - & $0.40 \pm 0.01$ \\
\hline 1467 & Germacrene D & $4.68 \pm 0.32$ & - \\
\hline 1473 & $\delta$-elemene & $2.12 \pm 0.06$ & $2.81 \pm 0.11$ \\
\hline 1480 & $(+)$ Ledene & - & $1.32 \pm 0.06$ \\
\hline 1483 & $\delta$-Gurjunene & $0.50 \pm 0.01$ & $0.33 \pm 0.01$ \\
\hline 1501 & $\beta$-cadinene & $\mathbf{1 0 . 0 0} \pm 1.03$ & $1.62 \pm 0.12$ \\
\hline 1508 & Trans Nerolidol & $3.18 \pm 0.25$ & - \\
\hline 1528 & (-) Spathulenol & $7.62 \pm 0.66$ & $6.77 \pm 0.92$ \\
\hline 1531 & Guaiol & $1.74 \pm 0.20$ & $0.20 \pm 0.06$ \\
\hline 1545 & $\delta$-Eudesmol & $2.06 \pm 0.05$ & $6.06 \pm 0.81$ \\
\hline 1549 & Caryophyllen oxide & - & $0.14 \pm 0.01$ \\
\hline 1553 & Elemol & - & $0.18 \pm 0.01$ \\
\hline 1560 & $\delta$-cadinol & $1.89 \pm 0.11$ & $0.24 \pm 0.03$ \\
\hline 1572 & $\beta$-Eudesmol & $2.31 \pm 0.20$ & $0.90 \pm 0.04$ \\
\hline 1576 & Bulnesol & $1.18 \pm 0.34$ & $0.37 \pm 0.02$ \\
\hline 1584 & Globulol & $1.58 \pm 0.03$ & $0.79 \pm 0.01$ \\
\hline 1598 & $\alpha$-Farnesene & $0.31 \pm 0.04$ & - \\
\hline 1612 & $(\mathrm{Z}, \mathrm{E})$ Farnesol & $0.25 \pm 0.02$ & $0.67 \pm 0.12$ \\
\hline 1622 & Phytol & $0.01 \pm 0.00$ & $0.22 \pm 0.01$ \\
\hline 1659 & Cubenol & - & $2.01 \pm 0.12$ \\
\hline 1682 & $\beta$-Selinenol & - & $\mathbf{9 . 7 1} \pm 0.22$ \\
\hline 1690 & $\beta$-caryophyllen oxide & - & $0.41 \pm 0.03$ \\
\hline
\end{tabular}




\begin{tabular}{llll}
\hline \multicolumn{2}{c}{ Table 2 } & (continued) & \\
\hline RI $^{\mathrm{a}}$ & Compounds & & \\
\hline 1703 & Ledene oxide & T. polium & microphylla \\
1715 & (2,E) Farnesol & - & $0.71 \pm 0.05$ \\
1726 & Aromadendrene oxide & - & $0.66 \pm 0.02$ \\
1752 & Junipene & - & $0.49 \pm 0.01$ \\
1773 & Longifolene & - & $0.89 \pm 0.02$ \\
1797 & 9,10 dehydro isolongifolene & - & $0.66 \pm 0.03$ \\
1808 & Cis Z $\alpha$-bisabolene epoxide & - & $1.27 \pm 0.42$ \\
1931 & Gembrene & - & $0.18 \pm 0.02$ \\
1937 & Isoaromadendrene epoxide & - & $0.20 \pm 0.05$ \\
1955 & 8-Cedren 13 ol & - & $0.37 \pm 0.01$ \\
2067 & $\beta-R e t i n o l$ & - & $0.36 \pm 0.03$ \\
2122 & Trans Z, $\alpha$ bisabolene epoxide & - & $0.33 \pm 0.05$ \\
2258 & Testololactone & - & $0.04 \pm 0.01$ \\
2306 & Ferruginol & - & $0.14 \pm 0.01$ \\
\hline
\end{tabular}

Notes: ${ }^{\mathrm{a}}$ : Retention indices; ${ }^{\mathrm{b}}$ : Compounds are listed in order of their elution from an HP-5MS column.

\subsection{Phenolic Content}

The principal aim of the current investigation was to highlight the differences in secondary metabolites contents between the methanolic and infusion extracts of 2 Lamiaceae species (Table 3). The obtained data shows the existence of significant variations of the total content of polyphenols in extracts obtained from the 2 species. In fact, the extracts from $S$. microphylla presented the highest contents in plolyphenols than extracted from $T$. polium. In addition, the infusions were rich in polyphenols $(39 \mathrm{mg} \mathrm{GAE} / \mathrm{g}$ DW for $S$. microhylla and $11.2 \mathrm{mg}$ GAE/g DW for T. polium) than the methanolic extracts (23.4 mg GAE/g DW for $S$. microhylla and $11.2 \mathrm{mg} \mathrm{GAE} / \mathrm{g} \mathrm{DW}$ for $T$. polium). The infusion extract of $T$. polium presented the highest content in flavonoids compounds $(7.72 \mathrm{mg}$ CE/g DW) those reported in the infusion extract of $S$. microphylla and methanolic extract of T. polium $(2.2 \mathrm{CE} / \mathrm{g} \mathrm{DW})$ followed by the methanolic extract of $S$. microphylla (1.7 CE/g DW).

Table 3: Phenolic compounds of infusion and methanolic extracts of Salvia microphylla and Teucrium polium. Values given are means (represent standard deviation) of 3 independent experiments

\begin{tabular}{lllll}
\hline Plants & & $\begin{array}{l}\text { Total phenolic content } \\
\text { (mg GAE/g DW) }\end{array}$ & $\begin{array}{l}\text { Flavonoids content } \\
\text { (mg CE/g DW) }\end{array}$ & $\begin{array}{l}\text { Tannins content } \\
\text { (mg TAE/g DW) }\end{array}$ \\
\hline S. microphylla & Infusion & $39 \pm 0.2^{\mathrm{a}}$ & $2.2 \pm 0.09^{\mathrm{b}}$ & $3.4 \pm 0.03^{\mathrm{a}}$ \\
& ME & $23.4 \pm 0.09^{\mathrm{b}}$ & $1.7 \pm 0.03^{\mathrm{c}}$ & $2.9 \pm 0.1^{\mathrm{b}}$ \\
T. polium & Infusion & $11.2 \pm 0.06^{\mathrm{c}}$ & $7.72 \pm 0.11^{\mathrm{a}}$ & $0.41 \pm 0.01^{\mathrm{c}}$ \\
& ME & $10.1 \pm 0.04^{\mathrm{c}}$ & $2.25 \pm 0.01^{\mathrm{b}}$ & $0.24 \pm 0.01^{\mathrm{d}}$ \\
\hline
\end{tabular}

Notes: ME: Methanolic extract; GAE: Gallic acid equivalents; DW: Dry weight; CE: (+)-catechin equivalent, TAE: Tannic acid equivalent. Means with different letters are different $(P<0.05)$. 
Concerning the tannins, the methanolic extract of T. polium has the lowest contents of these compounds (0.24 mg TAE/g DW). The highest tannin contents were registered in infusion extract from S. microphylla (3.4 mg TAE/g DW).

\subsection{Antioxidant Activity}

The obtained data showed clearly that the antioxidant activity of tested extracts varied significantly among the species and nature of extracts regardless of the used test (Table 4). The results of the scavenging DPPH radical method demonstrated that the activity was more important in both infusion extracts in particularly the T. polium $\left(\mathrm{IC}_{50}=0.02 \mathrm{mg} / \mathrm{mL}\right)$.

Table 4: Radical scavenging activity, metal chelating power and reducing power assay of essential oil, infusion and methanolic extract of $S$. microphylla and T. polium represented by $\mathrm{IC}_{50}(\mathrm{mg} / \mathrm{mL})$. Values given are means (error bars represent standard deviations) of 3 independent experiments. Means with different letters are different $(P<0.05)$

\begin{tabular}{llll}
\hline & Extracts & S. microphylla & T. polium \\
\hline DPPH & EO & $1.12 \pm 0.03^{\mathrm{b}}$ & $1.29 \pm 0.06^{\mathrm{b}}$ \\
& Infusion & $0.16 \pm 0.02^{\mathrm{c}}$ & $0.02 \pm 0.01^{\mathrm{c}}$ \\
& ME & $0.83 \pm 0.06^{\mathrm{a}}$ & $0.56 \pm 0.04^{\mathrm{a}}$ \\
Iron chelating & EO & $1.62 \pm 0.02^{\mathrm{a}}$ & $1.38 \pm 0.03^{\mathrm{a}}$ \\
& Infusion & $0.07 \pm 0.01^{\mathrm{c}}$ & $0.65 \pm 0.05^{\mathrm{b}}$ \\
& ME & $0.65 \pm 0.03^{\mathrm{b}}$ & $0.95 \pm 0.02^{\mathrm{b}}$ \\
Reducing power & EO & $1.42 \pm 0.05^{\mathrm{b}}$ & $2.34 \pm 0.01^{\mathrm{a}}$ \\
& Infusion & $0.026 \pm 0.01^{\mathrm{c}}$ & $0.33 \pm 0.04^{\mathrm{b}}$ \\
& ME & $0.33 \pm 0.02^{\mathrm{a}}$ & $3.4 \pm 0.06^{\mathrm{a}}$ \\
\hline
\end{tabular}

The iron-chelating power was used to determine the ability of plant extracts to chelate metal ions. From Table 4, it can be concluded that the T. polium methanolic extract had the higher chelating power and so the highest $\mathrm{IC}_{50}(0.95 \mathrm{mg} / \mathrm{mL})$. This activity was less important in the $\mathrm{MeOH}$ extract of $S$. microphylla and both infusion extracts.

The reducing power of iron was estimated by the effective concentration $\left(\mathrm{EC}_{50}\right)$. The low reducing power of the extract corresponds to a high $\mathrm{EC}_{50}$ value. The results summarized in the Table 4 demonstrated that the infusion extract of $S$. microphylla has inferred the highest reducing power with $\mathrm{EC}_{50}=0.026 \mathrm{mg} / \mathrm{L}$ followed by infusion extract of $T$. polium and methanolic extract of $S$. microphylla.

\subsection{Antimicrobial Activity}

The antibacterial and antifungal activities of tested essential oil, methanolic, and infusions extracts were determined using 2 methods: the disc diffusion assay and the broth dilution methods. The results of the antibacterial activities of $T$. polium and $S$. microphylla are summarized in Tables 5 and 6, respectively. The obtained data indicated that the investigated methanolic extracts displayed antibacterial activities with the diameters of inhibition zones (IZ) varied between 11 to $16 \mathrm{~mm}$ but the infusions extracts of both species were not active against the tested strains. In fact, the methanolic extract of $S$. microphylla $(\mathrm{IZ}=12$ to $16 \mathrm{~mm})$ showed high antimicrobial activity against the tested strains than T. polium ones $(\mathrm{IZ}=11$ to $15 \mathrm{~mm})$. The important antibacterial power was observed against gram-positive bacteria $(E$. coli and $P$. aeruginosa). 
Table 5: Antibacterial activity: IZ $(\mathrm{mm})$, MIC and $\mathrm{MBC}(\mu \mathrm{g} / \mathrm{mL})$ of Methanolic extract of $S$. microphylla (MES) and T. polium (MET). Means with different letters are different $(P<0.05)$

\begin{tabular}{|c|c|c|c|c|c|}
\hline \multirow[t]{2}{*}{ Micro-organisms } & \multicolumn{3}{|c|}{ Inhibition zone diameters (mm) } & \multirow{2}{*}{$\frac{\mathrm{MIC}}{\mu \mathrm{g} / \mathrm{mL}}$} & \multirow{2}{*}{$\frac{\mathrm{MBC}}{\mu \mathrm{g} / \mathrm{mL}}$} \\
\hline & MES & MET & Antibiotics & & \\
\hline E. coli ATCC 8739 & $16^{\mathrm{a}}$ & $14^{\mathrm{b}}$ & $24^{1}$ & $8.3^{\mathrm{a}}$ & $16.6^{\mathrm{b}}$ \\
\hline S. typhimurium NCTC 6017 & $14^{\mathrm{b}}$ & $13^{\mathrm{bc}}$ & $23^{1}$ & $8.3^{\mathrm{a}}$ & $16.6^{\mathrm{b}}$ \\
\hline A. hydrophila $\mathrm{EI}$ & $14^{\mathrm{b}}$ & $13^{\mathrm{bc}}$ & $23^{1}$ & $16.6^{\mathrm{b}}$ & $33.3^{\mathrm{c}}$ \\
\hline P. aeruginosa ATCC 27853 & $16^{\mathrm{a}}$ & $14^{\mathrm{b}}$ & $21^{1}$ & $8.3^{\mathrm{a}}$ & $16.6^{\mathrm{b}}$ \\
\hline S. aureus ATCC 29213 & $14^{\mathrm{b}}$ & $14^{\mathrm{b}}$ & $20^{1}$ & $8.3^{\mathrm{a}}$ & $16.6^{\mathrm{b}}$ \\
\hline L. monocytogenes ATCC 7644 & $13^{\mathrm{bc}}$ & $11^{\mathrm{d}}$ & $18^{1}$ & 16.6 & $33.3^{\mathrm{c}}$ \\
\hline B. Cereus ATCC 1247 & $15^{\mathrm{ab}}$ & $13^{\mathrm{bc}}$ & $21^{1}$ & $16.6^{\mathrm{b}}$ & $33.3^{\mathrm{c}}$ \\
\hline Asp. Flavus ATCC 60045 & $14^{\mathrm{b}}$ & $15^{\mathrm{ab}}$ & $11^{2}$ & $16.6^{\mathrm{b}}$ & $33.3^{\mathrm{c}}$ \\
\hline Asp. Niger ATCC 60045 & $12^{\mathrm{c}}$ & $13^{\mathrm{bc}}$ & $12^{2}$ & $16.6^{\mathrm{b}}$ & $33.3^{\mathrm{c}}$ \\
\hline C. albicans ATCC 10231 & $12^{\mathrm{c}}$ & $13^{b c}$ & $17^{2}$ & $16.6^{\mathrm{b}}$ & $33.3^{c}$ \\
\hline
\end{tabular}

Note: ${ }^{1}$ Gentamicin. ${ }^{2}$ Amphotricin.

Table 6: Antibacterial activity: IZ (mm), MIC and MBC (mg/mL) of essential oil of S. microphylla (EOS) and T. polium (EOT). Means with different letters are different $(P<0.05)$

\begin{tabular}{lllllll}
\hline Micro-organisms & \multicolumn{3}{c}{ Inhibition zone diameters $(\mathrm{mm})$} & & $\mathrm{MIC}$ & $\mathrm{MBC}$ \\
& EOS & EOT & $\begin{array}{l}\text { Antibiotic } \\
\text { (Gentamicin) }\end{array}$ & \\
\cline { 2 - 5 } & & $11 \pm 0.03^{\mathrm{a}} / \mathrm{mL}$ & $\mu \mathrm{g} / \mathrm{mL}$ \\
\hline E. coli ATCC 8739 & $11 \pm 0.5^{\mathrm{a}}$ & 24 & $275^{\mathrm{a}}$ & $550^{\mathrm{b}}$ \\
P. aeruginosa ATCC 27853 & $13 \pm 0.05^{\mathrm{c}}$ & $10 \pm 0.8^{\mathrm{a}}$ & 21 & & $275^{\mathrm{a}}$ & $550^{\mathrm{b}}$ \\
L. monocytogenes ATCC 7644 & $12 \pm 0.02^{\mathrm{b}}$ & $14 \pm 0.5^{\mathrm{b}}$ & 18 & & $275^{\mathrm{a}}$ & $550^{\mathrm{b}}$ \\
\hline
\end{tabular}

The screening of the antibacterial activity of essential oil of $S$. microphylla and T. polium was studied against 3 bacteria. The tested EOs exhibited a moderate effect against E. coli, P. aeruginosa and $L$. monocytogenes with zone diameters were 11,13 , and $12 \mathrm{~mm}$, respectively. These data showed clearly that the effect of essential oil varied among the studied strains which can be due to the compositions of these extracts.

Based on these data, it can be concluded that the methanolic extract had an important antimicrobial activity than the EOs.

\section{Discussion}

The composition of essential oils of Lamiaceae is characterized by great diversity between species. Each plant has its own footprints [35]. The variation in the chemical composition of essential oils depends on several factors including season, geographic origin, environmental factors, extraction methods, plant organ, phenological stage, and genetic differences [36].

The data of the chemical composition of the essential oil of $S$. microphylla shows that the major compounds are $\beta$-caryophyllene (13.32\%), 1.8 cineole (11.25\%), Cis p-Menthane 3 one $(10.74 \%)$, and $\beta$ Selinenol $(9.71 \%)$. 
Several works have studied the variation of the chemical composition of the essential oil of $S$. microphylla. Lima et al. [37] reported that (E)-caryophyllene (15.35\%), $\alpha$-eudesmol (14.06\%), $\beta$ eudesmol (8.74\%) and $\partial$-eudesmol (7.64\%) are the major compounds of the essential oil of $S$. microphylla. In addition, Aydogmuş et al. [15] showed the presence of 2 major compounds which are: eudesmol and 8- $\alpha$-hydroxy- $\beta$-eudesmol. The identified compounds of EO of $S$. micrphylla were $\alpha$-pinene, $\beta$-pinene, camphene, $\delta$-3-carene, limonene, 1,8-cineole, camphor, borneol, bornyl acetate, (E)karyophyllene, $\alpha$-copaene, globulol, spatulenol, eudesmol, and $\beta$-eudesmol [38].

The present study showed that the major compounds of the essential oil of $T$. polium are $\beta$-cadinene (10\%), $\beta$-citronellol (8.5\%), Carvacrol (7.63\%), and Eugenol (7.15). On the other hand, the literature has shown a variation between the chemical compositions according to the geographical origin [39] of the species. For example, myrcene (15.3\%), germacrene D (9.0\%), $\alpha$-pinene $(6.6 \%)$, and $\alpha$-cadinol $(5.1 \%)$ were the main components of the essential oil of Tunisian $T$. polium (39), The main compounds of $T$. polium from Northwest Algeria were germacrene D (25.81\%), bicyclogermacrene (13\%), $\beta$-pinene (11.69\%), and carvacrol ( 8.93\%) [40].The major compound of the essential oil of Jordanian T. polium being 8-cedren-13-ol (24.8\%) [41]. The composition of the essential oil of T. polium is characterized by the chemotype of the plant [42] depending on the part of the used plant, its stage of growth as well as the nature of the soil and growing conditions [39]. According to Boulila et al. [39], the chemical composition of essential oils of the species T. polium ssp. Polium in Tunisia, gives contents of major compounds which are 1,8 Cineol (17.66\%), $\alpha$-Pinene (8.05\%), and Cis Verbenol (7.49\%).

Our results on the chemical composition of T. polium essential oil differ from those obtained for the same species in other countries. In France, the species contains high levels of $\alpha$-pinene, $\beta$-pinene, germacrene D, $\beta$ caryophyllene, sabinene, and myrcene [43].

In Greece, it is rich in t-cadinol, -cadinol, $\beta$-caryophyllene, karyophylene oxide, and undecane [44]. The essential oil, extracted from samples of T. polium from Turkey and Serbia, is dominated by $\beta$-pinene [45]. Myrcene is the main petroleum compound of T. polium in Tunisia [39].

In addition to the genotypic and environmental effects (geographical origin), the regional variation (between countries) would also result from the variation in the composition of essential oils.

The phenolic content varies qualitatively and quantitatively from one plant to another. This can be attributed to several factors, including climatic and environmental factors: geographic area, drought, soil, attacks, and diseases... etc., the genetic makeup, the time of harvest, and the stage of development of the plant [46]. The extraction and the quantification methods may also influence the estimate of the content of total phenols. It has been proven that their contents and those of flavonoids are high when the plant's living environment is not adequate, in which case the plant promotes the synthesis of secondary metabolites in order to adapt and survive [47].

The antioxidant activity of the tested essential oils is probably linked to the major compounds which are mainly monoterpenes and sesquiterpenes for the essential oils of Salvia and Teucrium. These compounds exhibit important antioxidant properties. In general, essential oils rich in oxygenated compounds exhibit a more marked anti-radical activity than those containing hydrocarbon terpenes [48].

From the obtained results in these tests, it is evident that the interaction of an antioxidant with DPPH depends on its chemical structure. Some compounds react very quickly with DPPH. Athamena et al. [49] also found that this activity differs depending on the used test. This may explain this variation in the obtained results. It is important to note the fact that in the FRAP test all reduced substances (not just phenolic compounds) react in the reaction medium [50].

The results of the antimicrobial activity of essential oils of Salvia and Teucrium are similar, in most cases to the results described in the literature for the antimicrobial activities of other species of the genus Salvia 
[6,51]. For example, Sage had bactericidal effects on Candida albicans, Streptococci, Pneumococcus, Staphylococcus aureus, and Proteus [52].

The diameters of inhibition zones observed for the essential oil as well as the various Salvia tested extracts ranged from 11 to $16 \mathrm{~mm}$. Generally, this activity is attributed to the presence of 8-cineole and trans-caryophyllene [53,54].

Data on the antimicrobial activity of $T$. polium show that the extracts are more active compared to the essential oil. It should be noted, however, that these zones of inhibition are lower than those of the reference used antibiotics.

The activity of the essential oils of plants of this genus is linked to their composition, in particular compounds such as d-limonene, $\delta$-cadinene, and $\beta$-caryophyllene [54].

In reality, even if the antimicrobial activity of essential oil is often attributed essentially to its major compounds, it is known that the synergistic or antagonistic effect of the compounds in the mixture must be considered [55]. In addition, components of essential oils in lower amounts may also contribute to antimicrobial activity, possibly involving some type of synergy with other active compounds [40]. Many aromatic plants as well as the essential oils themselves have a strong antimicrobial power. They are even sometimes used as preservatives. This power is exerted against pathogenic bacteria, which alter membrane structures and functionality.

\section{Conclusions}

To the best of our knowledge, this is the first work reporting the phytochemical investigation of essential oil, methanolic and infusion extracts of S. microphylla growing in Tunisia. The antioxidant and antimicrobial activities also were evaluated. Infusion extract showed to not be antibacterial power at the tested concentrations, while the antioxidant properties were extremely important compared to that of the EOs. Concerning $T$. polium, the results show the richness of all the extracts by secondary metabolites which are endowed by important biological activities.

From a general point of view, our findings confirm the importance of bioactive plant molecules, and therefore it will be important to maintain the productivity and stability of cultivated plants.

Acknowledgement: One of the authors thanks Mr. R. El Mokni for his help to identify the plant material.

Funding Statement: The authors acknowledge funding supported by Campus France as part of the Scientific Stay at High Level received by AK and supported by CRITTBois and LERMAB of University of Lorraine, Epinal, France.

Conflicts of Interest: The authors declare that they have no conflicts of interest to report regarding the present study.

\section{References}

1. Karpiński, T. M. (2020). Essential oils of Lamiaceae family plants as antifungals. Biomolecules, 10(1), 103.

2. Judd, W. S., Campbell, C., Kellogg, E. A., Steven, P. F. (2002). Botanique Systématiqueune Perspective Phylogénétique, pp. 467. Traduction et révision scientifique de la $1^{\text {ère }}$ édition américaine par Jules Bouharmont et Charles-Marie Evrard. De Boeck Université.

3. Fotovvat, M., Radjabian, T., Saboora, A. (2019). HPLC fingerprint of important phenolic compounds in some Salvia L. species from Iran. Records of Natural Products, 13, 37-49. DOI 10.25135/rnp.72.18.02.228.

4. Khadhri, A., Bouali, I., Aouadhi, C., Lagel, M. C., Masson, E. et al. (2019). Determination of phenolic compounds by MALDI-TOF and essential oil composition by GC-MS during three development stages of Origanum majorana L. Biomedical Chromatography, 33(11), e4665. DOI 10.1002/bmc.4665. 
5. Tepe, B., Daferera, D., Sokmen, A., Sokmen, M., Polissiou, M. (2005). Antimicrobial and antioxidant activites of essential oil and various extracts of Salvia tomentosa miller. Food Chemistry, 90(3), 333-340. DOI 10.1016/j. foodchem.2003.09.013.

6. Kivrak, I., Duru, M. E., Oeztuerk, M., Mercan, N., Harmandar, M. et al. (2009). Antioxidant, anticholinesterase and antimicrobial constituents from the essential oil and ethanol extract of Salvia potentillifolia. Food Chemistry, 116, 470-479. DOI 10.1016/j.foodchem.2009.02.069.

7. Walker, J. B., Sytsma, K. J., Treutlein, J., Wink, M. (2004). Salvia (Lamiaceae) is not monophyletic: Implications for the systematics, radiation, and ecological specializations of Salvia and tribe Mentheae. American Journal of Botany, 91, 1115-1125. DOI 10.3732/ajb.91.7.1115.

8. Standley, P., Williams, L. (1973). Labiateae. Fieldiana: Botany, 24, 237-317. DOI 10.2307/1221181.

9. Ozdemir, C., Senel, G. (1999). The morphological, anatomical and karyological properties of Salvia sclarea L. Turkish Journal of Botany, 23, 7-18.

10. Alizadeh, A., Shaabani, M. (2012). Essential oil composition phenolic content, antioxidant and antimicrobial activity in Salvia officinalis L. cultivated in Iran. Advances in Environmental Biology, 6(1), 221-226.

11. Wang, J., Xu, J., Gong, X., Yang, M., Zhang, C. et al. (2019). Biosynthesis, chemistry, and pharmacology of polyphenols from Chinese Salvia species: A review. Molecules, 24(1), 155. DOI 10.3390/molecules24010155.

12. Szentmihályi, K., Then, M., Csedő, C. (2004). Comparative study on tannins, flavonoids, terpenes and mineral elements of some Salvia species. Acta Horticulturae, 629, 463-470. DOI 10.17660/ActaHortic.2004.629.60.

13. Sheikh, K. A., Maqsood, M., Rehman, M. U., Sarwar, S., Qayyum, A. A. et al. (2021). Biosynthesis of polyphenols in Salvia species. Biological and Clinical Sciences Research Journal, e018. DOI 10.54112/bcsrj. v2021i1.64.

14. Argueta, V. A. (1994). Atlas de las Plantas de la Medicina Tradicional Mexicana, pp. 1786. México: Instituto Nacional Indigenista.

15. Aydogmuş, Z., Yeşilyurt, V., Topcu, G. (2006). Constituents of Salvia microphylla. Natural Product Research, 20(8), 775-781. DOI 10.1080/14786410500462843.

16. Couplan, F. (2002). Dictionnaire étymologie de Botanique, pp. 238. Paris: Nestlé.

17. Grubesic, R. J., Vladimir-Knezevic, S., Kremer, D., Kalodera, Z., Vukovic, J. (2007). Trichome micromorphology in Teucrium (Lamiaceae) species growing in Croatia. Biologia, Bratislava, 62(2), 148-156. DOI 10.2478/s11756007-0023-6.

18. Abdollahi, M., Karimpour, H., Monsef-Esfehani, H. R. (2003). Antinociceptive effects of Teucrium polium L. total extract and essential oil in mouse writhing test. Pharmacological Research, 48, 31-35. DOI 10.1016/S1043-6618 (03)00059-8.

19. Stella, S., Predrag, L., Arieh, B. (2010). The effect of an aqueous extract of Teucrium polium on glutathione homeostasis in vitro: A possible mechanism of its hepatoprotectant action. Advances in Pharmacological Sciences, 10, 1-7. DOI 10.1155/2010/938324.

20. Ferrer-Gallego, P. P., Roselló, R., Gómez, J., Laguna, E., Peris, J. B. (2019). Proposal to conserve the name Teucrium polium (Labiatae) with a conserved type. Taxon, 68(4), 865-866. DOI 10.1002/tax.12106.

21. Panovska, T. K., Kulevanova, S., Gjorgoski, I., Bogdanova, M., Petrushevska, G. (2007). Hepatoprotective effect of the ethyl acetate extract of Teucrium polium L. against carbon tetrachloride-induced hepatic injury in rats. Acta Pharmaceutica, 57(2), 241-248. DOI 10.2478/v10007-007-0020-x.

22. Kawashty, S. A., Gamal EL-Din, E. M., Saleh, N. A. M. (1997). The favonoid chemosystematics of two Teucrium species from Southern Sinai, Egypt. Biochemical Systematics and Ecology, 27, 657-660. DOI 10.1016/S03051978(97)00109-9.

23. Bezić, N., Vuko, E., Dunkić, V., Ruščić, M., Blazevic, I. et al. (2011). Antiphytoviral activity of sesquiterpene-rich essential oils from four croatian Teucrium Species. Molecules, 16(9), 8119-8129. DOI 10.3390/molecules16098119.

24. Bahramikia, S., Yazdanparast, R. (2012). Phytochemistry and medicinal properties of Teucrium polium L. (Lamiaceae). Phytotherapy Research, 26(11), 1581-1593. DOI 10.1002/ptr.4617. 
25. Sharififar, F., Dehghn-Nudeh, G., Mirtajaldini, M. (2009). Major flavonoids with antioxidant activity from Teucrium polium L. Food Chemistry, 112(4), 885-888. DOI 10.1016/j.foodchem.2008.06.064.

26. Pottier-Alapetite, G. (1979). Flore de la Tunisie. Angiosperme Dicotylédone, d'apétales-Dialypétales, vol. 1, pp. 651. Edit Imp.Off.rep. Tunisie.

27. Karumi, Y., Onyeyili, P. A., Ogugbuaja, V. O. (2004). Identification of active princi-pals of M. balsamina (Balsam apple) leaf extract. International Journal of Medical Sciences, 4, 179-182. DOI 10.3923/jms.2004.179.182.

28. Adams, R. P. (2001). Identification of essential oil components by gaz chromatography/quadrupole mass spectroscopy, pp. 804. Carol Stream, Illinois: Allured Publishing.

29. Dewanto, V., Wu, X., Adom, K. K., Liu, R. H. (2002). Thermal processing enhances the nutritional value of tomatoes by increasing total antioxidant activity. Journal of Agricultural and Food Chemistry, 50, 3010-3014. DOI $10.1021 / \mathrm{jf0115589.}$

30. Sun, B., Richardo-da-Silivia, J. M., Spranger, I. (1998). Critical factors of vanillin assay for catechins and proanthocyanidins. Journal of Agricultural and Food Chemistry, 46, 4267-4274. DOI 10.1021/jf980366j.

31. Hatano, T., Kagawa, H., Yasuhara, T., Okuda, T. (1988). Two new flavonoids and other constituents in licore root: Their relative astringency and radical scavenging affects. Chemical and Pharmaceutical Bulletin, 36, 1090-2097. DOI 10.1248/cpb.36.2090.

32. Oyaizu, M. (1986). Studies on product of browning reaction prepared from glucose amine. Japanese Journal of Nutrition, 44, 307-315. DOI 10.5264/eiyogakuzashi.44.307.

33. Decker, E. A., Welch, B. (1990). Role of ferritin as a lipid oxidation catalyst in muscle food. Journal of Agricultural and Food Chemistry, 38(3), 674-677. DOI 10.1021/jf00093a019.

34. Bannour, M., Fellah, B., Rocchetti, G., Ashi-Smiti, S., Lachemeier, D. W. et al. (2017). Phenolic profling and antioxidant capacity of Calligonum azel Maire, a Tunisian desert plant. Food Research International, 101, 148-154. DOI 10.1016/j.foodres.2017.08.069.

35. Hilan, C., Sfeir, R., Jawish, D., Aitour, S. (2006). Huiles essentielles de certaines plantes médicinales libanaises de la famille des Lamiaceae. Lebanese Science Journal, 7(2), 13-22.

36. Abu darwish, M., Al-Ramamneh, E., Salamon, I., Abu-Dieyeh, Z., Al-Nawaiseh, M. et al. (2013). Determination of essential oil bioactive components and rosmarinic acid of Salvia officinalis cultivated under different intra-row spacing. Notulae Scientia Biologicae, 5(2), 198-203. DOI 10.15835/nsb529046.

37. Lima, R. K., Cardoso, M. D. G., Andrade, M. A., Guimarães, P. L., Batista, L. R. et al. (2012). Bactericidal and Antioxidant activity of essential oils from Myristica fragrans Houtt and Salvia microphylla H.B.K. Journal of the American Oil Chemists' Society, 89, 523-528. DOI 10.1007/s11746-011-1938-1.

38. Chialva, F., Monguzzi, F., Manitto, P. (1992). Composition of the essential oils of five Salvia species. Journal of Essential Oil Research, 4, 447-455. DOI 10.1080/10412905.1992.9698108.

39. Boulila, A., Bejaoui, A., Messaoud, C., Boussaid, M. (2008). Genetic diversity and population structure of Teucrium polium (Lamiacea) in Tunisia. Chemistry \& Biodiversity, 5, 1389-1400. DOI 10.1002/cbdv.200890127.

40. Belmekki, N., Bendimerad, N., Bekhechi, C., Fernandez, X. (2013). Chemical analysis and antimicrobial activity of Teucrium polium L. essential oil from Western Algeria. Journal of Medicinal Plants Research, 7(14), 897-902. DOI 10.5897/JMPR12.1160.

41. Aburjai, T., Hudaib, M., Cavrini, V. (2006). Composition of the essential oil from Jordanian Germander (Teucrium polium L.). Journal of Essential Oil Research, 18, 97-99. DOI 10.1080/10412905.2006.9699398.

42. Ashnagar, A., Gharib, N., Foroozanfar, S. (2007). Isolation and identification of the major chemical components found in the upper parts of Teucrium polium plants grown in Khuzestan province of Iran. Chinese Journal of Chemistry, 25, 1171-1173. DOI 10.1002/cjoc.200790218.

43. Chizzola, R. (2006). Volatile compounds from some wild growing aromatic herbs of the Lamiaceae from southern France. Plant Biosystems, 40(2), 206-210. DOI 10.1080/11263500600756587.

44. Vokou, D., Margaris, N. S. (1986). Variation of volatile oil concentration of mediterranean aromatic shrubs Thymus capitatus hoffmag et link, Satureja thymbra L., Teucrium polium L. and Rosmarinus officinalis. International Journal of Biometeorology, 30(2), 147-155. DOI 10.1007/BF02189456. 
45. Çakir, A., Mavi, A., Kazaz, C., Yildirim, A., Kufrevioglu, O. I. (2006). Antioxidant activities of the extracts and components of Teucrium orientale L. var. orientale. Turkish Journal of Chemistry, 30(4), 483-494.

46. Sharopov, F., Valiev, A., Sobeh, M., Arnold, E., Wink, M. (2018). Bioactivity of three Salvia species in relation to their total phenolic and flavonoid contents. Pharmaceutical and Chemical Journal, 52(7), 596-600. DOI 10.1007/ s11094-018-1866-6.

47. Apak, R., Güçlü, K., Demirata, B., Özyürek, M., Celik, S. E. et al. (2007). Comparative evaluation of various total antioxidant capacity assays applied to phenolic compounds with the CUPRAC assay. Molecules, 12(7), 1496-1547.

48. Miladi, H., Ben Slama, R., Mili, D., Zouari, S., Bakhrouf, A. et al. (2013). Chemical composition and cytotoxic and antioxidant activities of Satureja montana L. essential oil and its antibacterial potential against Salmonella Spp. strains. Journal of Chemistry, 2013, 9-18.

49. Athamena, S., Chalghem, I., Kassah-Laouar, A., Laroui, S., Khebri, E. S. (2010). Activité anti-oxydante et antimicrobienne d'extraits de Cuminum cyminum. Lebanese Science Journal, 11(1), 69.

50. Rojo, L., Benites, J., López, J., Rojas, M., Diaz, P. et al. (2009). Antioxidant capacity and polyphenolic content of twelve traditionally used herbal medicinal infusions from the South American Andes. Boletin Latinoamericano $y$ del Caribe de Plantas Medicinales y Aromaticas, 8(6), 498-508.

51. Hristova, Y., Gochev, V., Wanner, J., Jirovetz, L., Schmidit, E. et al. (2013). Chemical composition and antifungal activity of essential oil of Salvia sclarea L. from Bulgaria against clinical isolates of Candida species. Journal of BioScience and Biotechnology, 2, 39-44.

52. Bourret, J. C. (1981). Le Défi de la Médecine par les Plantes, pp. 458. Ed. EMPIRE, France.

53. Kelen, M., Tepe, B. (2008). Chemical composition, antioxidant and antimicrobial properties of the essential oils of three Salvia species from Turkish flora. Bioresource Technology, 99, 4096-4104.

54. Özkan, G., Sagdic, O., Gokturk, R. S., Unal, O., Albayrak, S. (2010). Study on chemical composition and biological activities of essential oil and extract from Salvia pisidica. Food Science and Technology, 43(1), 186-190.

55. Burt, S. (2004). Essential oils: Their antibacterial properties and potential applications in foods. International Journal of Food Microbiology, 94, 223-253. 